\title{
Surface-water purification using cellulose paper impregnated with silver nanoparticles
}

\author{
Shahad A. Raheem ${ }^{1}$ and Alaa H. Alfatlawi ${ }^{2}$ \\ ${ }^{1}$ College of Water Resources Engineering, Al-Qasim Green University, Hilla, Iraq \\ ${ }^{2}$ College of Engineering, University of Babylon, Hilla, Iraq \\ Correspondence: Shahad A. Raheem (shahad.ak@wrec.uoqasim.edu.iq) \\ and Alaa H. Alfatlawi (dr_ahw@yahoo.com)
}

Received: 5 July 2020 - Discussion started: 31 July 2020

Revised: 18 March 2021 - Accepted: 29 March 2021 - Published: 3 May 2021

\begin{abstract}
The objective of this study is to prepare a cellulose paper that was impregnated with silver nanoparticles (AgNPs) for the purpose of water purification (disinfection and filtration). AgNP papers were prepared by chemical reduction of silver nitrate $\left(\mathrm{AgNO}_{3}\right)$ with various concentrations $(0.005 \mathrm{M}, 0.015 \mathrm{M}, 0.03 \mathrm{M}$, and $0.05 \mathrm{M})$ using sodium borohydride $\left(\mathrm{NaBH}_{4}\right)$ as a reducing agent. Two ratios for $\mathrm{NaBH}_{4} / \mathrm{AgNO}_{3}$ of $2: 1$ and $10: 1$ were used to show the effect of reduction on the formation and removal efficiencies of AgNPs. AgNP papers were characterized using scanning electron microscopy and transmission electron microscopy. An acid digestion using $\mathrm{HCl}$ acid followed by analyzing the samples in an atomic absorption spectrometer (ASS) was conducted to measure the silver concentration in AgNP papers. TEM images showed that the silver nanoparticle size in the papers varied from 1.3 to $75 \mathrm{~nm}$.

Water samples, after filtration through AgNP papers, were analyzed using ASS to measure the silver concentration in the effluent water. AgNP paper antibacterial efficiency ranged from $99 \%$ to $100 \%$ for both reduction ratios. The average silver content in the effluent water for the three replicates ranged from 0 to $0.082 \mathrm{mgL}^{-1}$, which meets the United States Environmental Protection Agency (US-EPA) guideline for drinking water of less than $0.1 \mathrm{mgL}^{-1}$. Turbidity tests showed that these papers can be usefully used as point-of-use filters as the turbidity reduced to less than 1 NTU (Nephelometric Turbidity Units).
\end{abstract}

\section{Introduction}

Water is the common medium for many pathogens because it contains several bacteria, viruses, etc. The removal and inactivation of pathogenic microorganisms are the last steps in the treatment of drinking water (Phong et al., 2009). Although disinfection methods currently used in drinking water treatment can effectively control microbial pathogens, researches in the past few decades have revealed a dilemma between effective disinfection and formation of harmful disinfection byproducts (DBPs) (Li et al., 2008). When chlorine comes in contact with natural organic matter (NOM), carcinogenic compounds such as trihalomethanes (THMs) and haloacetic acids (HAAs) can be formed (Lalley et al., 2014).
Nanotechnology as well as its application is one of the rapidly developing sciences (Hossain et al., 2014). It is an important field of modern research dealing with the design, synthesis, and manipulation of a particle's structure ranging from approximately 1-100 nm (Korbekandi and Iravani, 2012). Among the most promising nanomaterials with antibacterial properties are metallic nanoparticles, which exhibit increased chemical activity due to their large surface to volume ratios and crystallographic surface structure (Savage and Diallo, 2005). Silver nanoparticles have proved to be most effective as they have good antimicrobial efficacy against bacteria, viruses and other eukaryotic microorganisms (Rai et al., 2009). The investigation of enhanced disinfection through the use of silver nanoparticle (AgNP) surface immobilization has been continually explored. From silver- 
doped hydroxyapatite coatings for reduced infection rate of implanted biomedical devices (Bai et al., 2012) to silverimpregnated ceramic filters for point-of-use treatment in rural Guatemala (Kallman et al., 2011), AgNP-coated surfaces have displayed a wide range of potential applications.

These commonly encountered materials could be beneficial in maintaining bacteria-free water which is being stored or transported. Graphene, activated carbon and nepheline films have also been studied for AgNP immobilized antibacterial surfaces (Lalley et al., 2014).

Cellulose materials serve as a good material for embedding metal nanoparticles due to their ability for metal ion absorption. Metal cations have an affinity for anionic carboxylic acid groups in paper; the porosity of the base paper allows microorganisms to come into contact with the biocide, but attachment to the fiber surfaces limits the level of silver in the effluent water. The large pore size in the paper allows for reasonably rapid flow by gravity without the need for pressure or suction (Dankovich and Gray, 2011).

The main objective of this study is to prepare disinfection material that has a high antibacterial efficiency, few side effects and can be readily used for water treatment. This study considers the use of nanotechnology, specifically the use of silver nanoparticles (AgNP) for water disinfection purposes (inactivating of Escherichia Coli, Staphylococcus aureus, Enterococcus faecalis, Klebsiella pneumoniae and Enterobacter aerogenes).

\section{Materials and methods}

\subsection{Sampling}

The study area was Shatt Al-Hilla river at Al-Hilla city, Iraq, from which the samples were taken during the period 2018 to 2019; this is because this river is the main source of water in the city, and we wanted to investigate the ability of AgNP papers to purify this water. Water sample characteristics are presented in (Table 1). A sample of $500 \mathrm{~mL}$ of water was grabbed and kept in precleaned plastic bottles. The samples were analyzed immediately to prevent any change in their quality that may occur.

\subsection{Preparation of AgNP papers}

A $10 \mathrm{~cm} \times 10 \mathrm{~cm} \times 0.8 \mathrm{~mm}$ off-white paper, $100 \%$ alpha cellulose, Whatman Gel Blot GB005, was used to embed silver nanoparticles. AgNP papers were prepared by in situ reduction of $\mathrm{AgNO}_{3}$ with various concentrations $(0.005 \mathrm{M}$, $0.015 \mathrm{M}, 0.03 \mathrm{M}$ and $0.05 \mathrm{M}$ ) and two reduction ratios of $2: 1$ and $10: 1$, to show the effect of increasing the concentration of the reducing agent on the formation of AgNPs. Each paper was soaked in $40 \mathrm{~mL}$ of $\mathrm{AgNO}_{3}$ solution for $30 \mathrm{~min}$; then it was washed with ethanol for 1 min to remove the excess $\mathrm{Ag}$ ions which were not adsorbed by the paper. To form AgNPs, the paper was placed in $40 \mathrm{~mL}$ of $\mathrm{NaBH}_{4}$ solution for
Table 1. Characteristics of raw water samples.

\begin{tabular}{|c|c|}
\hline Property & Value \\
\hline Turbidity, NTU (Nephelometric Turbidity Units) & 13.5 \\
\hline $\mathrm{pH}$ & 8.4 \\
\hline Total dissolved solids (TDS), $\mathrm{mgL}^{-1}$ & 921 \\
\hline Temperature, ${ }^{\circ} \mathrm{C}$ & 18.4 \\
\hline \multicolumn{2}{|l|}{ Bacteriological analysis } \\
\hline Escherichia coli, $\mathrm{CFU} \mathrm{mL}^{-1}$ (colony-forming unit) & 3300 \\
\hline Staphylococcus aureus, $\mathrm{CFU} \mathrm{\textrm {mL } ^ { - 1 }}$ & 7750 \\
\hline Enterococcus faecalis, $\mathrm{CFU} \mathrm{mL} \mathrm{m}^{-1}$ & 47100 \\
\hline Enterobacter aerogenes and Klebsiella pneumoniae, $\mathrm{CFU} \mathrm{mL}^{-1}$ & 3600 \\
\hline Proteus mirabilis, $\mathrm{CFU} \mathrm{mL}^{-1}$ & 150 \\
\hline
\end{tabular}

$1 \mathrm{~h}$. After that, the paper was soaked in deionized water for $30 \mathrm{~min}$. Then the paper was dried in the oven at $60^{\circ} \mathrm{C}$ for $2.5 \mathrm{~h}$. Figure 1 shows the papers before and after embedding with AgNPs.

\subsection{Characterization}

The synthesized AgNP papers were characterized by scanning electron microscopy (SEM), type Quanta 450, available at the University of Babylon (College of Pharmacy) and transmission electron microscopy (TEM) available at AlNahrain University (College of Medicine).

\subsection{Acid digestion}

To determine the amount of dissolved silver in the AgNP paper, an acid digestion of the paper was performed, and then the amount of dissolved silver was analyzed with an atomic absorption spectrometer (AAS, type AA320N) available at the University of Babylon (College of Material Engineering). Approximately $100 \mathrm{mg}$ of the dried AgNP paper was reacted with $5 \mathrm{~mL}$ of nitric acid $\left(\mathrm{HNO}_{3}\right)$ and $5 \mathrm{~mL}$ of water. The mixture was boiled until the paper was disintegrated. A volume of $5 \mathrm{~mL}$ of $30 \%$ hydrogen peroxide $\left(\mathrm{H}_{2} \mathrm{O}_{2}\right)$ was added to the mixture to assist in the complete oxidation of the organic matter and to release additional metals into the solution. The mixture was boiled again, left to be cooled, and then filtered through Whatman filter paper (grade 41) with a diameter of $15 \mathrm{~cm}$; it was then diluted by adding $100 \mathrm{~mL}$ of water. The diluted mixture was tested for silver content using an AAS.

\subsection{Microbiological test}

Urinary tract infections (UTIs) chromogenic agar was prepared by suspending $47.5 \mathrm{~g}$ of the medium in $1 \mathrm{~L}$ of distilled water. The mixture was mixed well and dissolved by heating with frequent agitation. Then it was boiled for 1 min until complete dissolution. The medium was sterilized by placing it in an autoclave at $121^{\circ} \mathrm{C}$ for $15 \mathrm{~min}$; then it was cooled to $45-50^{\circ} \mathrm{C}$, mixed well, dispensed into plates and left to solid- 


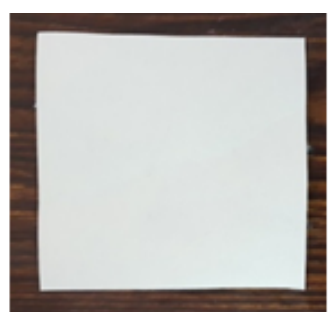

(a)
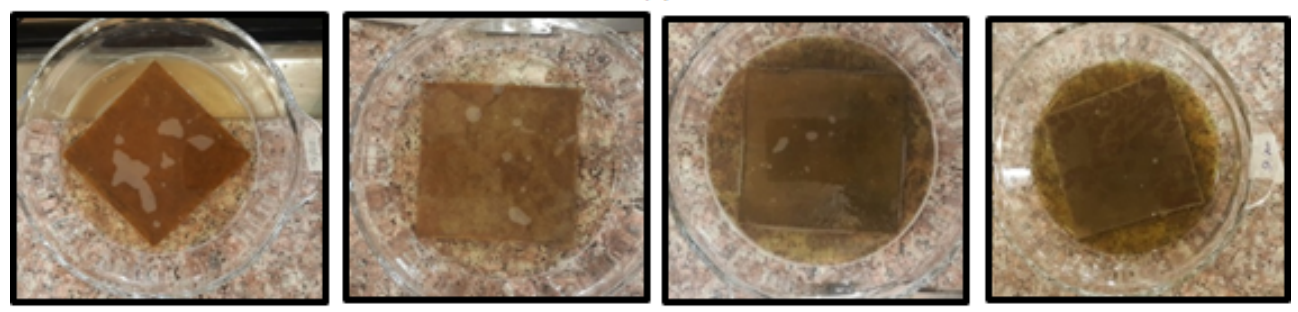

(b)
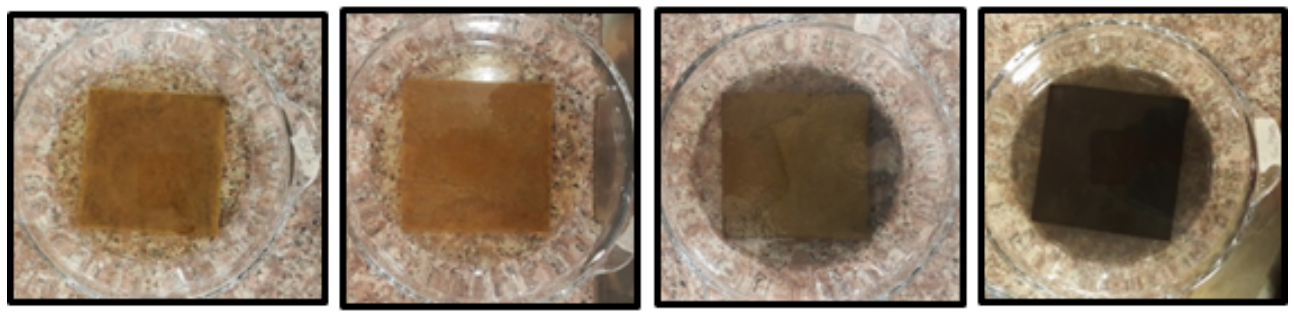

(c)

Figure 1. Cellulose papers: (a) before being impregnated with $\mathrm{AgNPs}$, (b) during preparation of $\mathrm{AgNPs}$ with a $\mathrm{NaBH}_{4} / \mathrm{AgNO}_{3}$ ratio of $2: 1$, and (c) during preparation of $\mathrm{AgNPs}$ with a $\mathrm{NaBH}_{4} / \mathrm{AgNO}_{3}$ ratio of $10: 1$.

ify. The dehydrated medium was homogeneous, free-flowing and beige in color.

The samples were cultured using the serial dilutions method: $1 \mathrm{~mL}$ of the sample was diluted in $9 \mathrm{~mL}$ of distilled water (1:10 dilution). This process repeated until a $1: 100000$ dilution was reached. A volume of $0.1 \mathrm{~mL}$ of each dilution was spread over a medium plate, and then the plates were incubated at $37^{\circ} \mathrm{C}$ for $48 \mathrm{~h}$ in an incubator (LIB-030M). The colonies were counted by eye and colony-forming units per milliliter were calculated using the following equation (Hameed et al., 2015):

$\frac{\mathrm{CFU}}{\mathrm{mL}}=\frac{\text { No. of colonies } \cdot \text { Dilution factor }}{\text { Volume of the sample plated }(\mathrm{mL})}$.

\section{Results and discussion}

\subsection{Paper characterization}

The AgNP papers were characterized by SEM and TEM. Figure 2 represents the images obtained by SEM to show the presence of AgNPs in paper fibers and the images obtained by TEM to determine the particle sizes of AgNPs. Table 2 represents the particle sizes of AgNPs obtained by TEM.
Table 2. The particle sizes of AgNPs obtained by TEM.

\begin{tabular}{lrr}
\hline & \multicolumn{2}{c}{ Nanoparticle size range, $\mathrm{nm}$} \\
\cline { 2 - 3 } $\mathrm{AgNO}_{3}$ & $2: 1$ & $10: 1$ \\
concentration, & $\mathrm{NaBH}_{4} / \mathrm{AgNO}_{3}$ & $\mathrm{NaBH}_{4} / \mathrm{AgNO}_{3}$ \\
$\mathrm{M}$ & ratio & ratio \\
\hline 0.005 & $6.86-75$ & $2.028-39.395$ \\
0.015 & $3.399-42.521$ & $1.333-39.643$ \\
0.03 & $3.064-50.311$ & $1.314-23.431$ \\
0.05 & $2-21.84$ & $0.943-20.044$ \\
\hline
\end{tabular}

TEM images and results presented in Table 2 showed that an excess of sodium borohydride reductant (10:1 ratio of sodium borohydride to silver nitrate) resulted in more uniform and smaller nanoparticles. This can be due to the increased speed of reduction with the increment in the reducing agent (Quintero-Quiroz et al., 2019) . These results agree with the findings of the previous studies concerning this subject. 

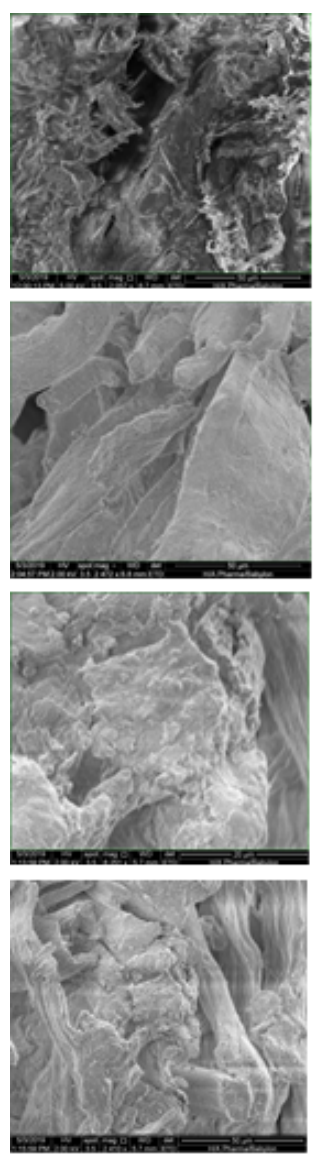

(a)
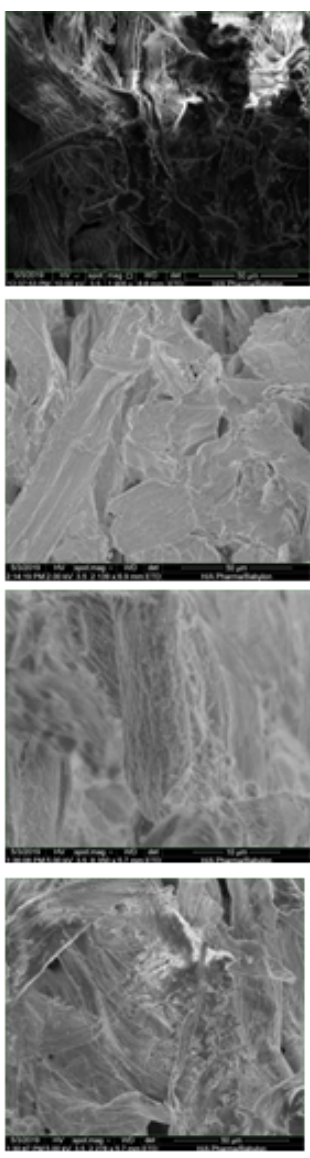

(b)
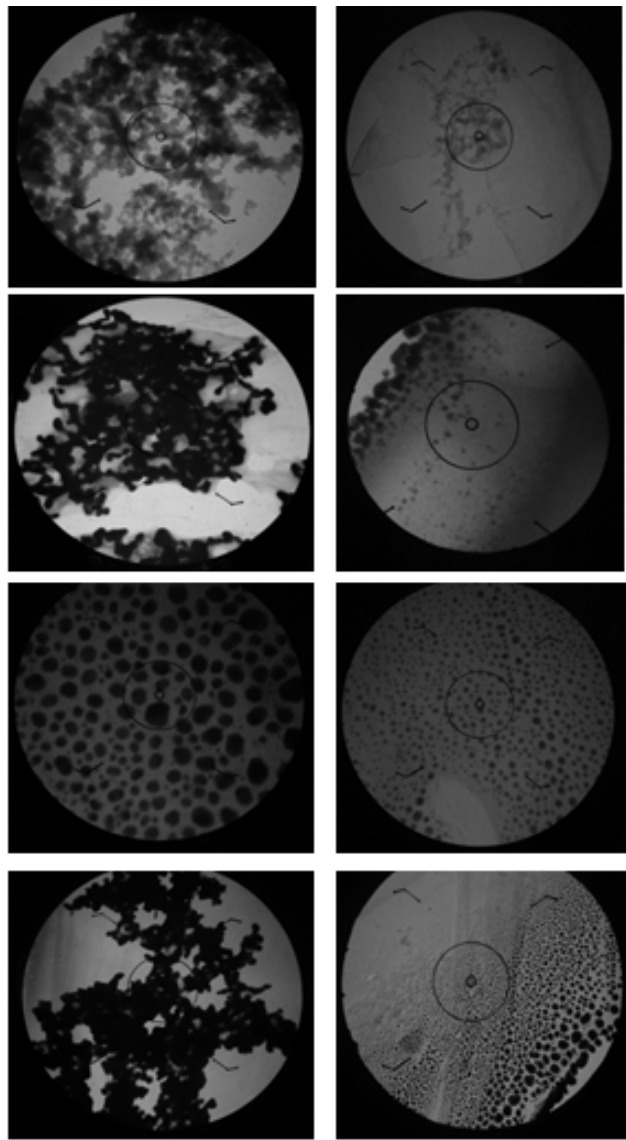

(c)

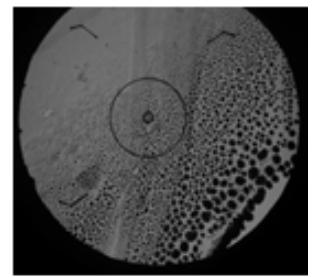

(d)

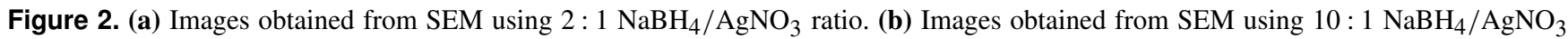
ratio. (c) TEM images using $2: 1 \mathrm{NaBH}_{4} / \mathrm{AgNO}_{3}$ ratio. (d) TEM images using $10: 1 \mathrm{NaBH}_{4} / \mathrm{AgNO}_{3}$ ratio.

Table 3. AAS test showing the silver content of each paper.

\begin{tabular}{lrr}
\hline & \multicolumn{2}{c}{ Silver content $\left(\mathrm{mg} \mathrm{Ag} \mathrm{g}^{-1}\right)$ of dried paper } \\
\cline { 2 - 3 } $\mathrm{AgNO}_{3}$ & $2: 1$ & $10: 1$ \\
concentration, & $\mathrm{NaBH}_{4} / \mathrm{AgNO}_{3}$ & $\mathrm{NaBH}_{4} / \mathrm{AgNO}_{3}$ \\
$\mathrm{M}$ & ratio & ratio \\
\hline 0.005 & 3.958 & 4.343 \\
0.015 & 4.625 & 4.698 \\
0.03 & 7.007 & 7.911 \\
0.05 & 7.867 & 8.769 \\
\hline
\end{tabular}

\subsection{Acid digestion}

Acid digestion was performed to determine the silver content of the paper. The results were obtained by using AAS (type AA320N). Table 3 shows the results of the AAS test.

The acid digestion of AgNP papers showed silver content ranging from 3.9 to $8.7 \mathrm{mg} \mathrm{Agg}^{-1}$ (milligram $\mathrm{Ag}$ per dry gram of paper). The increase in silver content of the paper correlates with the increase in precursor silver ion concentration of the solution in which the papers were soaked, prior to reduction (Dankovich and Gray, 2011). For the same concentration of $\mathrm{AgNO}_{3}$, the $\mathrm{NaBH}_{4} / \mathrm{AgNO}_{3}$ ratio of $10: 1$ resulted in more silver content than the $2: 1$ ratio. These results agree with the findings of the previous studies concerning this subject.

\subsection{Removal efficiencies of bacteria}

Figures 3 and 4 show the effect of the silver content in the AgNP paper on the removal efficiency of different types of bacteria with a $\mathrm{NaBH}_{4} / \mathrm{AgNO}_{3}$ ratio of $2: 1$ and $10: 1$, respectively.

As shown in Figs. 3 and 4, the minimal inhibitory concentration (MIC), which is the lowest concentration of silver nanoparticles needed to inactivate the bacteria, for E. coli for all three filtration times was $4.62 \mathrm{mg} \mathrm{Ag} \mathrm{g}^{-1}$ dry paper for a $\mathrm{NaBH}_{4} / \mathrm{AgNO}_{3}$ ratio of $2: 1$, while for $10: 1$, the MIC for complete inactivation of $E$. coli was $4.34 \mathrm{mg} \mathrm{Ag} \mathrm{g}^{-1}$ dry paper. The MIC for complete inactivation of Staphylococcus aureus was $7.01 \mathrm{mg} \mathrm{Agg}^{-1}$ dry paper for $2: 1 \mathrm{ra}-$ tio and $4.7 \mathrm{mg} \mathrm{Agg}^{-1}$ dry paper for $10: 1$ ratio. The MIC for complete inactivation for Enterococcus faecalis was 


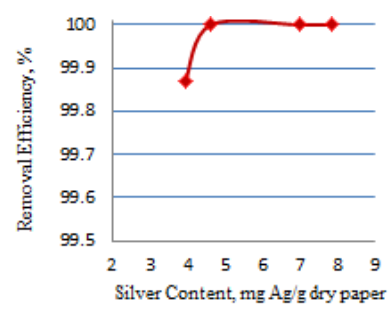

(a)

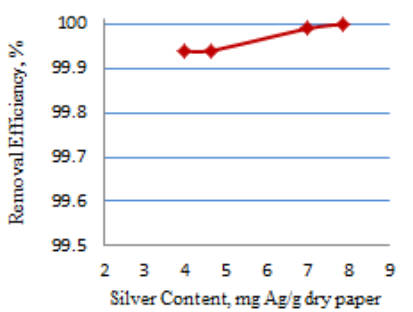

(c)

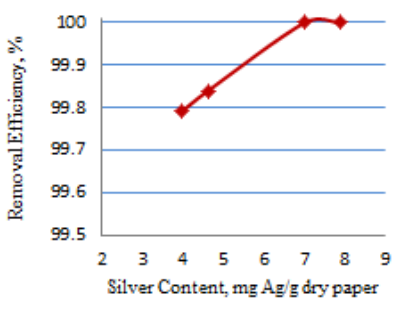

(b)

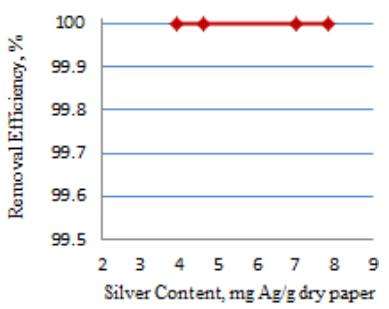

(d)

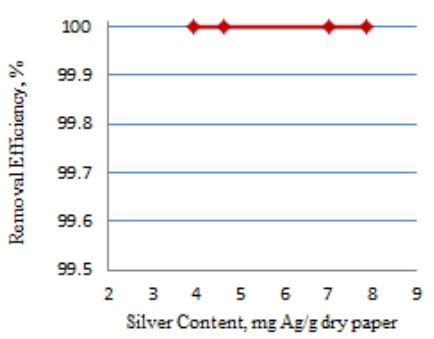

(e)

Figure 3. The removal efficiency of different types of bacteria with $\mathrm{NaBH}_{4} / \mathrm{AgNO}_{3}$ ratio of $2: 1$ : (a) E. coli, (b) Staphylococcus aureus, (c) Enterococcus faecalis, (d) Enterobacter aerogenes and Klebsiella pneumoniae, and (e) Proteus mirabilis.

$4.01 \mathrm{mg} \mathrm{Agg}^{-1}$ dry paper for $2: 1$ ratio and $4.7 \mathrm{mg} \mathrm{Agg}^{-1}$ dry paper for $10: 1$ ratio. The removal efficiency for Enterobacter aerogenes and Klebsiella for all silver contents and both ratios was $100 \%$.

It was observed that for all types of bacteria, the $\mathrm{NaBH}_{4} / \mathrm{AgNO}_{3}$ ratio of $10: 1$ resulted in complete inactivation of bacteria in less silver content than the $2: 1$ ratio and that the $10: 1$ ratio resulted in smaller and more uniform $\mathrm{Ag}$ NPs, which led to better contact between the AgNPs and the bacteria (Bakhtiari-Sardari et al., 2020). These results agree with the findings of the previous studies concerning this subject.

\subsection{Analysis of silver content in the effluent}

Due to possible human health effects from silver exposure, the silver content in the effluent water was analyzed by AAS. Table 4 represents the relationship between the silver content in the paper and silver release in the effluent.

As shown in Table 4, the average silver content in the effluent water for the three replicates ranged from 0 to $0.082 \mathrm{mg} \mathrm{L}^{-1}$, which meets the United States Environmen-

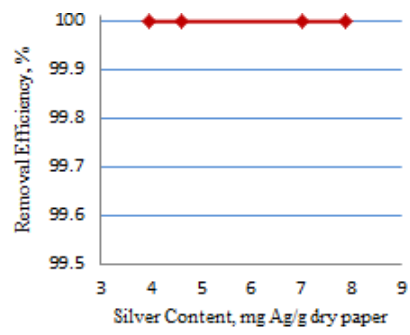

(a)

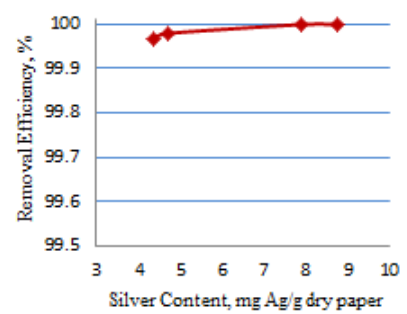

(c)

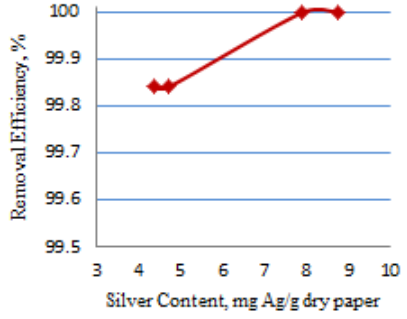

(b)

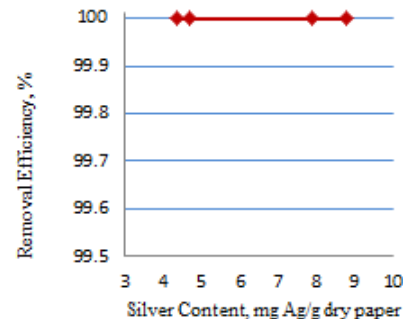

(d)

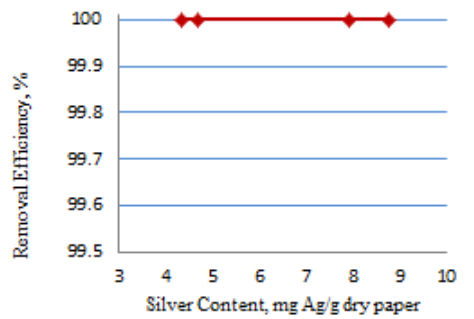

(e)

Figure 4. The removal efficiency of different types of bacteria with $\mathrm{NaBH}_{4} / \mathrm{AgNO}_{3}$ ratio of 10:1: (a) E. coli. (b) Staphylococcus aureus. (c) Enterococcus faecalis. (d) Enterobacter aerogenes and Klebsiella pneumoniae. (e) Proteus mirabilis.

Table 4. The relationship between the silver content in the papers and silver in the effluent water.

\begin{tabular}{lrr}
\hline & \multicolumn{2}{c}{ Silver content in the Effluent, $\mathrm{mg} \mathrm{L}^{-1}$} \\
\cline { 2 - 3 } $\begin{array}{lrr}\mathrm{AgNO}_{3} \\
\text { concentration, }\end{array}$ & $2: 1$ & $10: 1$ \\
$\mathrm{M}$ & $\mathrm{NaBH}_{4} / \mathrm{AgNO}_{3}$ & $\mathrm{NaBH}_{4} / \mathrm{AgNO}_{3}$ \\
ratio & ratio \\
\hline 0.005 & 0 & 0 \\
0.015 & 0 & 0 \\
0.03 & 0.021 & 0.043 \\
0.05 & 0.043 & 0.082 \\
\hline
\end{tabular}

tal Protection Agency (US-EPA) guideline for drinking water of less than $0.1 \mathrm{mgL}^{-1}$ (EPA, 2018). This was due to the stability of silver nanoparticle in the cellulose paper. Sodium borohydride acts not only as a reducing agent but also as an ion stabilizer, which prevents silver ions from aggregation. Moreover, hydroxyl and ether groups in the cellulose fiber play an important role in the stabilization of metal nanoparti- 
Table 5. Turbidity results before and after filtration through AgNP paper for both reduction ratios.

\begin{tabular}{|c|c|c|c|c|}
\hline \multirow{2}{*}{$\begin{array}{l}\mathrm{AgNO}_{3} \\
\text { concentration, } \\
\mathrm{M}\end{array}$} & \multicolumn{2}{|c|}{$2: 1 \mathrm{NaBH}_{4} / \mathrm{AgNO}_{3}$ ratio } & \multicolumn{2}{|c|}{$\begin{array}{c}10: 1 \mathrm{NaBH}_{4} / \mathrm{AgNO}_{3} \\
\text { ratio }\end{array}$} \\
\hline & $\begin{array}{l}\text { Turbidity } \\
\text { before } \\
\text { filtering } \\
\text { through } \\
\text { papers } \\
\text { (NTU) }\end{array}$ & $\begin{array}{l}\text { Turbidity } \\
\text { after } \\
\text { filtering } \\
\text { through } \\
\text { papers } \\
\text { (NTU) }\end{array}$ & $\begin{array}{l}\text { Turbidity } \\
\text { before } \\
\text { filtering } \\
\text { through } \\
\text { papers } \\
\text { (NTU) }\end{array}$ & $\begin{array}{l}\text { Turbidity } \\
\text { after } \\
\text { filtering } \\
\text { through } \\
\text { papers } \\
\text { (NTU) }\end{array}$ \\
\hline 0.005 & 13.5 & 0.92 & 13.5 & 0.82 \\
\hline 0.015 & 12.1 & 0.33 & 12.1 & 0.12 \\
\hline 0.03 & 12.1 & 0.22 & 12.1 & 0.13 \\
\hline 0.05 & 13.5 & 0.87 & 13.5 & 0.81 \\
\hline
\end{tabular}

cles (Pinto et al., 2012). These results agree with the findings of the previous studies concerning this subject.

\subsection{Turbidity removal}

Turbidity tests were conducted using a turbidity meter, SN 10/1467, Germany, available at the University of Babylon (College of Engineering, Environmental Engineering Department). Table 5 represents the results obtained before and after filtration through AgNP papers.

As shown in Table 5, the cellulose paper acts as a good point-of-use filter as all the turbidities were reduced to an acceptable level. Reducing the papers with the 10:1 $\mathrm{NaBH}_{4} / \mathrm{AgNO}_{3}$ ratio reduced the turbidity better than the $2: 1 \mathrm{NaBH}_{4} / \mathrm{AgNO}_{3}$ ratio.

\section{Conclusions}

Sliver nanoparticles used in this work exhibit a broad size distribution with highly reactive facets. It was observed that chemical reduction of $\mathrm{AgNO}_{3}$ by using $\mathrm{NaBH}_{4}$ as a reducing agent resulted in spherical silver nanoparticles. The ratio for $\mathrm{NaBH}_{4} / \mathrm{AgNO}_{3}$ of $10: 1$ resulted in smaller sizes of silver nanoparticle and more silver content than the ratio of 2:1 for the same $\mathrm{AgNO}_{3}$ concentration. AgNP paper provided rapid and effective bactericidal activity as the bacterially contaminated water was filtered through the paper; this is especially important for Enterococcus faecalis, which is for the first time tested for removal by AgNPs. AgNP papers can be used as good point-of-use filters. 
Appendix A: Abbreviations

$\begin{array}{ll}\text { AgNPs } & \text { silver nanoparticles } \\ \mathrm{AgNO}_{3} & \text { silver nitrate } \\ \mathrm{NaBH}_{4} & \text { sodium borohydride } \\ \mathrm{SEM} & \text { scanning electron microscopy } \\ \text { TEM } & \text { transmission electron microscopy } \\ \mathrm{AAS} & \text { atomic absorption spectrometer } \\ \text { DBPs } & \text { disinfection byproducts } \\ \mathrm{NOM} & \text { natural organic matter } \\ \text { THMs } & \text { trihalomethanes } \\ \mathrm{HAA} & \text { haloacetic acid } \\ \mathrm{TDS} & \text { total dissolved solid } \\ \mathrm{HCl} & \text { hydrochloric acid } \\ \mathrm{HNO} & \\ \mathrm{H}_{2} \mathrm{O}_{2} & \text { nitric acid } \\ \mathrm{UTI} & \text { hydrogen peroxide } \\ \mathrm{MIC} & \text { minary tract infections } \\ \end{array}$


Data availability. No data sets were used in this article.

Author contributions. SAR has done samples and data collection and lab experiments as well as writing and editing the paper. AHA role was supervising the process of data and samples collection and experiments and made the final correction to writing.

Competing interests. The authors declare that they have no conflict of interest.

Acknowledgements. This study was supported by the Department of Environmental Engineering in the University of Babylon. We also appreciate the support of the sanitary lab in the College of Engineering that helped carry out this work.

Review statement. This paper was edited by Luuk Rietveld and reviewed by Mona Soliman and one anonymous referee.

\section{References}

Bai, X., Sandukas, S., Appleford, M., Ong, J. L., and Rabiei, A.: Antibacterial effect and cytotoxicity of Ag-dopedfunctionally graded hydroxyapatite coatings, J. Biomed. Mater. Res. B, 100B, 553-561, 2012.

Bakhtiari-Sardari, A., Mashreghi, M., Eshghi, H., Behnam-Rasouli, F., Lashani, E., and Shahnavaz, B.: Comparative evaluation of silver nanoparticles biosynthesis by two cold-tolerant Streptomyces strains and their biological activities, Biotechnol. Lett., https://doi.org/10.1007/s10529-020-02921-1, in press, 2020

Dankovich, T. A. and Gray, D. G.: Bactericidal Paper Impregnated with Silver Nanoparticles for Point-of-Use Water Treatment, Environ. Sci. Technol., 45, 1992-1998, https://doi.org/10.1021/es103302t, 2011

EPA: EPA 822-F-18-001, in: 2018 Edition of the Drinking Water Standards and Health Advisories, Office of Water, US Environmental Protection Agency Washington, DC, 2018.
Hameed, U., Muhammad, A., Jahngeer, A.; and ul Haq, I.: Determination of Microbial load of Drinking Water from different areas of Lahore, Biologia (Pakistan), 61, 151-156, 2015.

Hossain, F., Perales-Perez, O. J., Hwang, S., and Román, F.: Antimicrobial nanomaterials as water disinfectant: applications, limitations and future perspectives, Sci. Total Environ., 466-467, 1047-1059, 2014.

Kallman, E. N., Oyanedel-Craver, V. A., and Smith, J. A.: Ceramic filters impregnated with silver nanoparticles for point-of-use water treatment in rural Guatemala, J. Environ. Eng., 137, 407-415, 2011.

Korbekandi, H. and Iravani, S.: Silver Nanoparticles, InTech, Intechopen, 978-953-51-0615-9, https://doi.org/10.5772/34157, 2012.

Lalley, J., Dionysios, D., Varma, R. S., Shankara, S., Yang, D. J., and Nadagouda, M. N.: Silver-based antibacterial surfaces for drinking water disinfection - an overview, Curr. Opin. Chem. Eng., 3, 25-29, 2014.

Li, Q., Mahendra, S., Lyon, D. Y., Brunet, L., Liga, M. V., Li, D., and Alvarez, P. J.: Antimicrobial nanomaterials for water disinfection and microbial control: potential applications and implications, Water Res., 42, 4591-4602, https://doi.org/10.1016/j.watres.2008.08.015, 2008.

Phong, N. T., Thanh, N. K., and Phuong, P. H.: Fabrication of antibacterial water filter by coating silver nanoparticles on flexible polyurethane foams, J. Phys. Conf. Ser., 187, 012079, https://doi.org/10.1088/1742-6596/187/1/012079, 2009.

Pinto, R. J. B., Neves, M. C., Pascoal Neto, C., and Trindade, T.: Composites of Cellulose and Metal Nanoparticles, in: Nanocomposites - New Trends and Developments, edited by: Ebrahimi, F., IntechOpen, https://doi.org/10.5772/50553, 2012.

Quintero-Quiroz, C., Acevedo, N., Zapata-Giraldo, J., Botero, L. E., Quintero, J., Zárate-Triviño, D., Saldarriaga, J., and Pérez, V. Z.: Optimization of silver nanoparticle synthesis by chemical reduction and evaluation of its antimicrobial and toxic activity, Biomater. Res., 24, 53-67, https://doi.org/10.1186/s40824-0190173-y, 2019.

Rai, M., Yadav, A., and Gade, A.: Silver nanoparticles as a new generation of antimicrobials, Biotechnol. Adv., 27, 76-83, 2009.

Savage, N. and Diallo, M. S.: Nanomaterials and water purification: Opportunities and challenges, J. Nanopart. Res., 7, 331342,2005 